\title{
CORRIGENDUM
}

\section{Evaluation of The Farms Producing Dry Bean Landraces By Capital Approach in The Middle Kızılırmak Valley of Turkey - CORRIGENDUM}

\author{
Mustafa Kan, Arzu Kan, Ömer Sözen, Ufuk Karadavut and Mehmet Yağmur
}

DOI: https://doi.org/10.1017/S1479262119000169 Published online by Cambridge University Press: 06 May 2019

Three authors' names were omitted from a reference and it was incorrectly published as:

Şehirali S, Özgen M, Karagöz A, Sürek M, Adak S, Güvenç İ and Kenar D (2005)

The correct reference is:

Şehirali S, Özgen M, Karagöz A, Sürek M, Adak S, Güvenç İ, Tan A, Burak M, Kaymak, H Ç, and Kenar D (2005)

\section{Reference}

Kan M., Kan A., Sözen Ö, Karadavut U., \& Yağmur M. (n.d.). Evaluation of the farms producing dry bean landraces by capital approach in the Middle Kizılirmak Valley of Turkey. Plant Genetic Resources: Characterization and Utilization, 1-10. doi:10.1017/ S1479262119000169 